\title{
カプセル内が液体薬剤である医薬品の投与量調節方法について 一小児患者を想定したラステット「25を用いた検討一
}

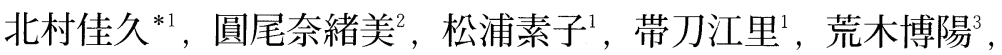 \\ 柴田和彦 ${ }^{1}$, 黒㟝勇二 ${ }^{2}$, 川㟝博己 ${ }^{2}$ ，五味田 裕 ${ }^{1}$ \\ 岡山大学医学部・茵学部附属病院薬剂部1 \\ 岡山大学大学院医柬薬総合研究科臨床薬学 ${ }^{2}$ \\ 愛媛大学医学部附属病院薬剂部 3
}

\section{Methods for Adjusting Dosages of Liquid Capsule Dosage Forms for Pediatric Patients}

\author{
Yoshihisa Kitamura*1, Naomi Maruo ${ }^{2}$, Motoko Matsuura', Eri Tatewaki ${ }^{1}$, Hiroaki Araki ${ }^{3}$, \\ Kazuhiko Shibata ${ }^{1}$, Yuji Kurosaki ${ }^{2}$, Hiromu Kawasaki ${ }^{2}$ and Yutaka Gomita ${ }^{1}$ \\ Department of Hospital Pharmacy, Okayama University Medical and Dental School ${ }^{1}$ \\ Department of Clinical Pharmaceutical Science, Graduate School of \\ Natural Science and Technology, Okayama University ${ }^{2}$ \\ Division of Pharmacy, Ehime University Hospital ${ }^{3}$
}

$\left[\begin{array}{l}\text { Received April 1, 2005 } \\ \text { Accepted July 7, } 2005\end{array}\right]$

The dosage of medications must often be adjusted for pediatric patients. When drugs are in tablet or capsule form, the dosage may be adjusted by breaking up tablets or removing the drug form capsules but when a capsule contains a liquid, dosage adjustment is difficult. For example, until November 2002, it was quite common for the antihypertensive drug Adalat ${ }^{\circledR}$ to be aspirated into a syringe from the capsule and then administered. We therefore investigated the safety of aspirating the liquid contents of 5 types of capsules into a syringe.

Through giving consultation on patient medication, we discovered that it was not possible to aspirate the contents of Lastet $^{\circledR}$ S25 into a syringe and for this reason decided to study ways of safely administering half of the etopside content $(12.5 \mathrm{mg})$ of Lastet ${ }^{\circledR} \mathrm{S} 25$. We found that Lastet ${ }^{\circledR} \mathrm{S} 25$ readily disintegrated in hot water $\left(55^{\circ} \mathrm{C}\right)$ and that half of the etopside content could be obtained by stirring the water. This study showed that the direct aspiration of the liquid content of capsules into a syringe for the purpose of dosage adjustment is hazardous and in the case of Lastet ${ }^{\circledR}$ S25, this problem could be solved by dissolving the capsule in hot water, stirring and then taking the liquid into the syringe. This method should be useful for administering less than standard doses of capsule dosage forms to pediatric patients when the capsule contains a liquid.

Key words — pediatrics, capsule formulation, Lastet ${ }^{\circledR}$ S25, disintegration, drug compliance

\author{
緒 \\ 言 \\ 小児への薬物投与は成人と異なるさまざまな問題点を \\ 考える必要がある。その中でも薬剤師は服薬コンプライ \\ アンスの向上を目指し, 調剤上の工夫ならびに適切な服 \\ 薬方法のアドバイスを行う必要がある。これまで，われ \\ われは小児の服薬コンプライアンス向上を目的として服
}

薬コンプライアンスの低下原因である医薬品の味・にお いに関しての改善方法 ${ }^{1-3)}$ および小児用胃挿管チューブ の薬剤による詰まりといった製剤の物性的問題 ${ }^{4}$ の解決 方法について検討し臨床現場で応用している．小児への 薬物投与に関して服薬コンプライアンスの向上以外に重 要な点として投与量の調節が考えられる。各剂形での投 与量の調節に関して, 注射薬は投与容量の調節で可能と なる，散剤・顆粒剤および液剤は注射薬同様に服用する 
容量で調節が可能である。さらに，錠剂およびカプセル 剂は一般に小児への投与量は成人と比較して低用量とな る。そのため, 腸溶性などの一部の医薬品を除き粉砕あ るいは脱カプセル化することにより, 適切な投与量の確 保が可能となる。しかしながら, カプセル剂の中で内容 物が液体であるカプセルについては調剤上投与量の調節 を行うことは内容物を正確に取り出すことが困難である ため難しいと想像される。これまで小児科領域の臨床現 場において，降圧薬であるニフェジピン製剤(アダラー ト®) (バイエル薬品(株)) は内容物を注射器で簡単に吸引 することが可能であるため, 吸引した液体内容物の投与 を行うことがしばしば見受けられた。アダラートを除 き, 多くのカプセル剂は液体内容物を取り出しての服用 は添付文書上に禁止の記載はないものの, 一般的には推 奨される服用方法とは考えにくい. しかしながら, 実際 の臨床では投与量の問題でカプセル剂の液体内容物を吸 引して服用しなければいけない症例も存在するため, 薬 凨師はその対応策を十分考慮する必要がある. 実際の症 例として, 岡山大学医学部・歯学部附属病院 (以下, 当 院と略す) 小児科において神経芽細胞腫で末梢血幹細胞 移植後の再発予防のために(4 歳) ラステット ${ }^{\circledR} \mathrm{S} 25$ (日本 化薬(株) を 1 日 1 カプセル朝 · 夕食後服用 (1 回0.5カプ セル服用)という処方の経験をした. ラステット ${ }^{\circledR} \mathrm{S} 25 に$ 関して医師は母親に液体内容物を注射器に吸い取ってか らその半量を患児に服用させるように指示を与えた。し かし, 後日に母親から「ラステット ${ }^{\circledR} \mathrm{S} 250$ 内容物が注 射器で吸えない」との訴えがあった。つまり，この訴え により薬剤師は内容物が液体であるカプセル剤の注射器 を用いての吸引することが可能な医薬品と不可能な医薬 品があることを認識したものの, その投与量の調節方法 についての十分な指導を行うことができなかった。つま り，薬剤師はカプセル内容物の採取により発生が予測さ れる問題点について事前に確認し, 処方医に情報提供し 医師はその情報をもとに治療を行う必要があると考えら れる。

これまで，與燕下障害があり錠剂などが服用できない場 合，錠剂およびカプセル剂をそのまま水に入れ崩壊・懸 濁させる簡易懸濁法による投与方法が報告されてい $る^{5-7)}$. 本法による経管投与できる医薬品の一覧は「内 服薬 経管投与ハンドブック」に報告されているもの $の^{5)}$, 懸濁時の医薬品の安定性または小児の服用を考慮 した服用量の調整などの詳細な報告はない。 そこで, 本 研究では臨床使用を想定し当院採用医薬品の中で内容物 が液体であるカプセル剤について注射器を用いて吸引手 技を行い，その手技の安全性および吸引可能か否かにつ いて検討を行った。次にこれまで液体内容物を吸引して 服用していたアダラート®を用いて吸引によって正確な 投与量を服用できるかについて検討を行った.ささら，
抗悪性腫瘍剂の院内取扱い指針 (日本病院薬剂師会学術 委員会第 1 小委員会)でランク $\mathrm{B}$ (取扱い上でやや注意を 要する)とされているラステット ${ }^{\circledR} \mathrm{S} 25$ を例として簡易懸 濁法により具体的に安全かつ正確に半量を服用できる方 法について検討を行い, 分割服用が実用可能か否かにつ いても検討を行った.

\section{方法}

\section{1. 試験医薬品および試薬}

試験医薬品にはアダラート ${ }^{\circledR}\left(\right.$ バイエル薬品(株)), $\mathrm{EPL}^{\circledR}$ カプセル (アルフレッサファーマ(侏)), ユベラNソフト® カプセル (エーザイ(株) $)$ ，ラステット ${ }^{\circledR} \mathrm{S} 25$ (日本化薬(侏) およびロノック®カプセル(小野薬品工業(株) を用いた。

\section{2. 注射器を用いた液体内容物吸引試験}

カプセル内容物吸引試験の試験者は岡山大学薬学部学 生 7 名で実施した．試験者に対して事前に本試験の意義 について説明し同意を得て実施した.各試験医薬品は2.5 $\mathrm{mL}$ の注射器 (テルモシリンジ : テルモ(株))に $27 \mathrm{G}(0.40 \times$ $19 \mathrm{~mm}$ ：テルモ注射針：テルモ(株))の注射針を装着し， カプセル内の液体内容物を吸引した。この条件で吸引で きなかった医薬品に関してのみ, $23 \mathrm{G}(0.65 \times 25 \mathrm{~mm}$ ：テ ルモ注射針：テルモ(株) の注射針を用いて液体内容物を 吸引した。なお，ラステット ${ }^{\circledR} \mathrm{S} 25 を$ 用いた液体内容物 吸引操作はバイオハザード対策用キャビネット (MHE130B2：三洋電機(株) 内で行った. さらに, 液体内容物 吸引操作を行った時の安全性について試験医薬品毎にア ンケート調査を行った。

\section{3. アダラートを用いた内容物吸引によるカプセルから の取り出し量ならびに注射器からの回収量の誤差}

試験にはアダラート®用いた。あらかじめ重量を測 定しておいた $27 \mathrm{G}$ 注射針付き注射器を用いてアダラー ト®から液体内容物を吸引し, 再度重量を測定して, そ の差を取り出し量とした。この注射器内の液体を別の容 器に移し, その重量を注射器からの回収量とした。

\section{4. ラステット ${ }^{\circledR} \mathrm{S} 25$ 用いた服用方法に関する検討}

実験にはラステット ${ }^{\circledR} \mathrm{S} 25 を$ 用いた。

1) カプセル溶解時の水温の影響

実験は $10 \mathrm{~mL}$ の水 $\left(25^{\circ} \mathrm{C}\right)$ および温湯 $\left(55^{\circ} \mathrm{C}\right)$ 中にカプセ ルを入れ，水中でのカプセルの変化を観察した.

2 ) 攪拌の有無によるにエトポシド含量変化

実験は $10 \mathrm{~mL}$ の温湯 $\left(55^{\circ} \mathrm{C}\right)$ でカプセルを溶解し, 溶解 直後， $0.5 ， 1 ， 3 ， 6$ および12時間後の水中のエトポ シド含量を測定した.エトポシドは水に極めて溶けにく く, 予備実験においてラステット ${ }^{\circledR} \mathrm{S} 25 を$ 温湯で溶解放 
置12時間後では下層部にラステット ${ }^{\circledR} \mathrm{S} 25$ の内容液体が 沈殿することを確認したため, 実験は攪拌群と放置群の 2 群に分けて行った. 攪挥群はスターラーを用いて常時 攪拌し, 中層部のエトポシド含量を測定した. カプセル を放置した群は温湯に放置直後から 5 分間のみ攪拌を行 い, その後は攪拌せずそのまま放置し, ラステット ${ }^{\circledR} \mathrm{S}$ 25の液体内容物のある下層部を避けその上部の中層部の エトポシド含量を測定した。放置12時間後に再度スター ラーにて 5 分間の攪找を行い，同様に中層部のエトポシ ド含量についても測定を行った。

3 ) 半量採取時の誤差の検討ならびに採取行為に関す るアンケート調査

実験はカプセルを $10 \mathrm{~mL}$ の温湯 $\left(55^{\circ} \mathrm{C}\right)$ で溶解し，ス ターラーを用いて 5 分間攪䢁した状態でガラス製のピ ペット $\left(\mathrm{PYREX}^{\circledR}\right.$ : 岩城硝子(株) または $10 \mathrm{~mL}$ の注射器 (テ ルモシリンジ:テルモ(株))を用いて $5 \mathrm{~mL}$ を採取し, 採 取した溶液 (採取側)ならびに残った溶液を再度ピペット および注射器を用いて採取した溶液(残量側) 中のエトポ シド含量を測定した.さらに，半量採取行為に対する安 全性について方法 2 と同様に岡山大学薬学部学生 7 名に 対してアンケート調査を行った。

4) エトポシド含量測定方法

エトポシド含量測定は shirazi ら $(2001)^{8)}$ の方法を参考 に行った. 試料中のエトポシドをジエチルエーテル（和 光純薬工業(株) で抽出し蒸発乾固した。 その残椬をアセ トニトリル (関東化学(株))で溶解し高速液体クロマトグラ フィー法(HPLC)により測定した，定量方法は内部標準 法を用い, 内部標準物質として $\mathrm{p}$ 一ヒドロキシ安息香酸 エチル (東京化成(株) を使用した。分析条件として，カラ ムは Inertsil ODS-2 4.6×150mm(ジールサイエンス(株)

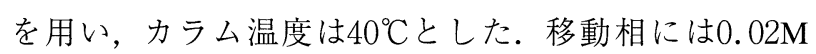

リン酸二水素カリウム溶液：アセトニトリルを60：40と なるように混合し移動相とした。流速は $1.0 \mathrm{~mL} / \mathrm{min}$ と し, 検出波長 $254 \mathrm{~nm}$ にて測定を行った。

\section{5. 統計処理}

実験結果の統計処理には Student's t-test を用い, 危険 率 $5 \%$ 以下を有意な差として表わした。

\section{結果}

\section{1. 注射器を用いた液体内容物吸引試験}

実際の臨床施行条件を想定し, 注射器を用いて液体内 容物の取り出しが可能か検討した(表 1 ). その結果, 試

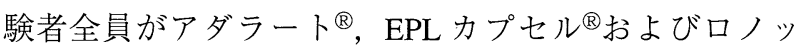
クカプセルは ${ }^{\circledR} 27 \mathrm{G}$ の注射針を使用して液体内容物を採 取することが可能と回答した. ユベラ Nソフトカプセ ル® 7 名中 5 名の試験者が不可能と回答した.さら に, ラステット ${ }^{\circledR} \mathrm{S} 25$ は試験者全員が採取不可能と回答 し，23G の注射針を使用しても多くの試験者が同様に採 取不可能と回答した. 図 1 には液体内容物の採取行為の 安全性についての結果を示した。 その結果, 薬剤の種類 に関係なく半数以上の試験者が「危険」もしくは「注意 を必要」と回答した. 特にラステット ${ }^{\circledR} \mathrm{S} 25$ は抗癌剤で あるので全員が「注意を必要」と回答した。

\section{2. アダラートを用いた液体内容物吸引によるカプセ ルからの取り出し量ならびに注射器からの回収量の誤差}

$27 \mathrm{G}$ の注射針を用いて液体内容物の採取が可能であっ たアダラート®を用いてカプセルからの取り出し量と注 射器からの回収量の違いについて検討を行った(図 2 ). その結果, 各群とも值にばらつきがあり, カプセルから

表 1. 各カプセル製剤からの液体内容物採取実験における 注射針の影響

\begin{tabular}{|l|c|c|c|c|}
\hline \multirow{2}{*}{} & \multicolumn{2}{|c|}{$27 \mathrm{G}$ 注射針 } & \multicolumn{2}{c|}{$23 \mathrm{G}$ 注射針 } \\
\cline { 2 - 5 } & 可 & 不可 & 可 & 不可 \\
\hline ラステット & 0 & 7 & 2 & 5 \\
\hline アダラート & 7 & 0 & & \\
\hline EPL & 7 & 0 & & \\
\hline ユベラNソフト & 2 & 5 & 2 & 5 \\
\hline ロノック & 7 & 0 & \multicolumn{2}{|l|}{} \\
\hline
\end{tabular}




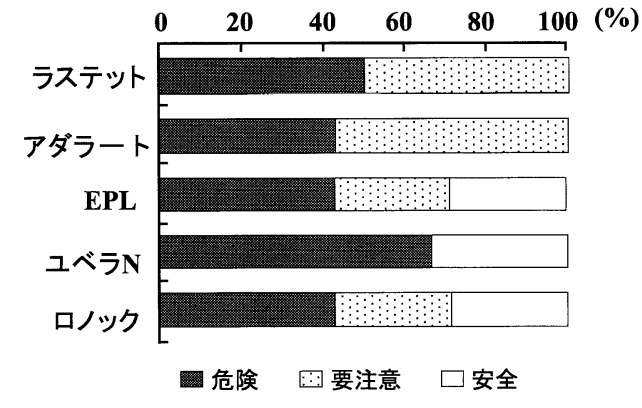

図 1. 薬学部学生による注射器を用いたカプセル剂 内の液体内容物採取行為の安全性に関するア ンケート結果

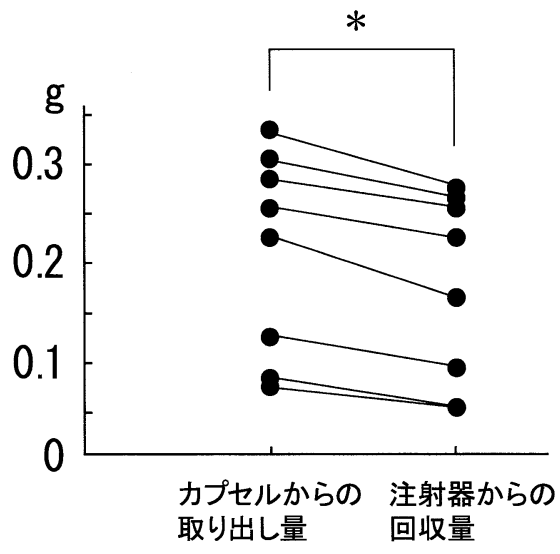

図 2.アダラートを用いた液体内容物採取による カプセルからの取り出し量ならびに注射器か らの回収量の誤差

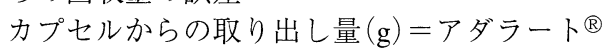
液体内容物吸引後の注射器の重量 $(\mathrm{g})$ - 空注 射器の重量 $(\mathrm{g})$, 注射器からの回収量 $(\mathrm{g})=$ (注射器より吐き出した重量 $(\mathrm{g})+$ 回収容器の 重量 $(\mathrm{g}))$ - 回収容器の重量 $(\mathrm{g}),{ }^{*}: \mathrm{P}<0.05$ (Student's t-test)

の取り出し量と比較して注射器からの回収量は有意な減 少を認めた。注射器からの回収率は約78\%であった。

\section{3. ラステット ${ }^{\circledR} \mathrm{S} 25$ 用いた服用方法に関する検討}

1）カプセル溶解時の水温の影響

水温 $25^{\circ} \mathrm{C}$ の条件にカプセルを放置すると 30 分後におい ても，カプセルは吸水と考えられる膨張を示すものの破 れることはなく液体内容物の溶出は認められなかった。

一方， $55^{\circ} \mathrm{C}$ の温湯に放置した場合放置直後からカプセル 中央部のゼラチンの帯部分から溶け始め， 2 分30秒後に は自然に破れ液体内容物の拡散が始まった。

2 ）攪拌の有無によるエトポシド含量変化

カプセルを水中で攪拌した群では, 溶解直後のエトポ シド含量は $25.11 \mathrm{mg}$ であり攪拌12時間後においてもエ
トポシド含量に変化を認めなかった。一方，攪拌せず水 中で放置した群では，放置12時間後では下層部に沈殿物 が認められ上層部におけるエトポシド含量は経時的に減 少した。しかし，放置12時間後で再度攪拌することによ りエトポシド含量は溶解直後 $(24.69 \mathrm{mg})$ と同程度であっ た(図3).

3 ）半量採取時の誤差の検討ならびに採取行為に関す るアンケート調査

ガラス製ピペットならびに注射器を用いて半量採取を 行った結果，それぞれ両群とも半量採取による誤差は認 められなかった(図4)。しかしながら，注射器を用いた 群ではガラス製ピペットと比較して明らかにエトポシド 含量の低下を認めた(図 4)。一方，このガラス製ピペッ 卜を用いた半量採取までの行為は 7 名中 5 名が「安全」 と回答した。残り 2 名は「注意を必要」と回答した(図 $5)$. さらに, 本行為と注射器を用いた液体内容物吸引 試験との比較では全員が「安全」と回答した(図 5 ).

\section{考察}

本実験に扔いて注射器を用いた採取試験において採取 可能な医薬品と不可能な医薬品が存在することが明らか となった。 その中で採取不可能であった原因として各医 薬品の液体内容物の形状㧍よび粘度の相違が関係してい
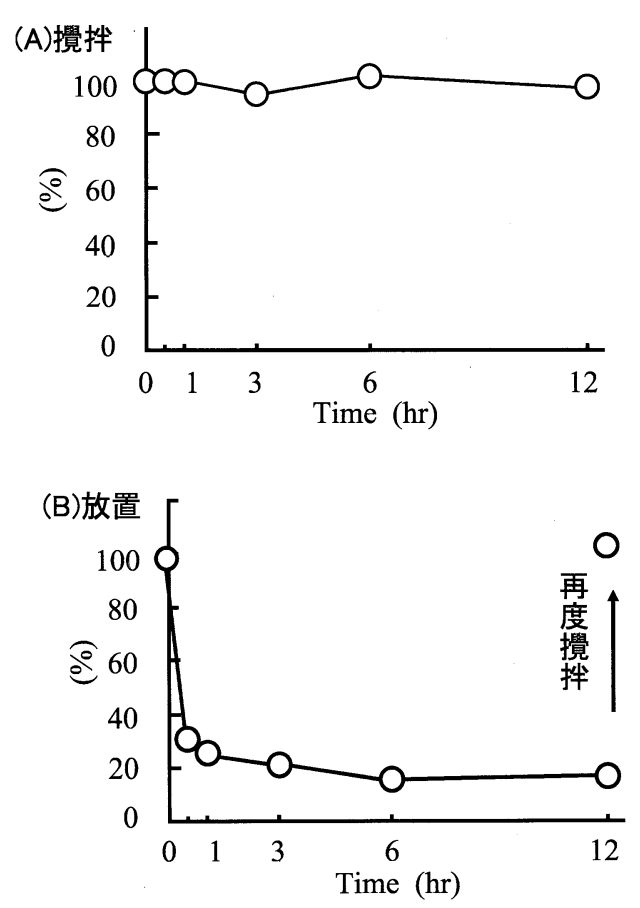

図 3. 攪拌の有無によるエトポシド含量変化 (A) 攪拌群, (B) 放置群 縦軸はカプセル溶解直後のエトポシド含量を 100\%ととして表した。横軸はカプセル溶解 後の時間を示す。例数は 6 例である. 


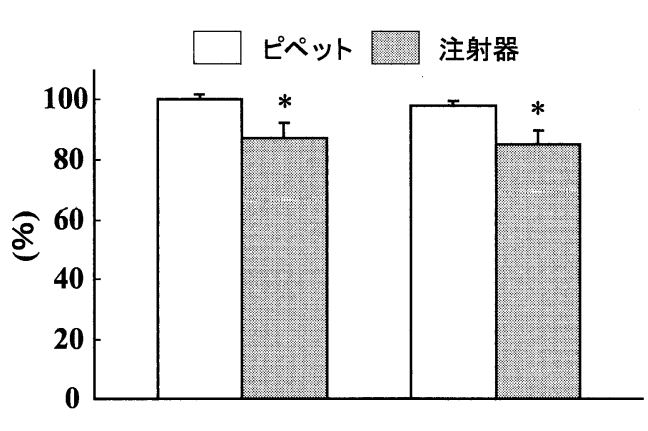

採取側

残量側

図 4. ラステット ${ }^{\circledR} \mathrm{S} 25$ 溶解後の半量採取時に用い る器具によるエトポシド含量変動の検討 縦軸はガラス製ピペットによって半量採取 されたエトポシド含量(採取側)を $100 \%$ と して表した。值は平均値士標準偏差で表し た。例数は 6 例である.**: $\mathrm{P}<0.05 \mathrm{vs}$ ピペット群 (Student's t-test)

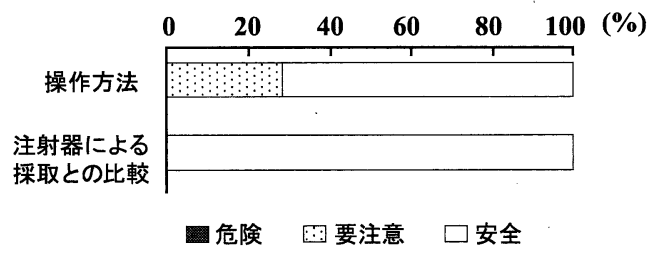

図 5. ラステット ${ }^{\circledR} \mathrm{S} 25$ 溶解後の半量採取行為の 安全性ならびに注射器を用いた液体内容 物採取行為との比較に関するアンケート 結果

ると考えられる．特に本実験において採取が不可であっ たユべラNソフトカプセル®は内容物に関して「帯黄白 色の粘稠な懸濁液又は半固体」と記載されており半固体 のような形状のため採取不可能であったと推察される. このようにカプセル内の性状についての情報は各医薬品 のインタビューフォームを参照するが, 多くの医薬品の 製剂の性状として「粘性の液体」との記載があるだけで, どの程度の粘性を有するのか明らかでない.つまり，こ のように内容液体物を採取する必要がある場合薬棛師は 事前に採取可能か判断する必要がある. 一方, 各医薬品 の注射器を用いた採取行為の安全性については医薬品の 種類に関係なく半数以上の試験者が危険もしくは注意を 必要と回答し，この行為自体に危険を感じることが明ら かとなった。一方, 安全であると回答した中で EPLカ プセル®はカプセルが大きく採取しやすいため，ロノッ クカプセル ${ }^{\circledR}$ はカプセルが透明で液体内容物が確認でき るとの回答であり，液体内容物の形状とは別にカプセル 自体の要因が考えられた。

医薬品・医療用具等安全性情報183号 (2002年11月28日 発表)において，ニフェジピン製剤の軟カプセル剤の使
用で「速効性を期待した本剤の舌下投与 (カプセルをか み砕いた後，口中に含むか又はのみこませること）は， 過度の降圧や反射性頻脈をきたすことがあるので，用い ないこと」と発表された。 それ以前は多くの領域におい て降圧目的で口腔内にてカプセルをかみ砕き舌下投与す ることが行われていた. 小児科領域では本剤の液体内容 物を注射器で採取後服用する症例も見受けられていた。 そこで, 本実験ではカプセルからの液体内容物の取り出 し量ならびに注射器からの回収量を検討した結果, 両群 とも值にばらつきが認められた。ささらに，最終的な注射 器からの回収率は理論值の約78\%であり，指示された服 用量ならびに毎回一定量を服用させることは困難である ことが明らかとなった。つまり，本剤ではカプセルをロ 腔内でかみ砕けば一定量のニフェジピンの服用は可能で あるものの, 注射器に吸い取ってからの服用は一定の投 与量を確保できないと考えられる。アダラート®は注射 器での採取は比較的可能な薬郕であるが(表 1 ), そのア ダラート®おいても採取量の相違が生じることより， 採取が不可能な薬剤ではさらに一定した投与量を服用で きない可能性が示唆された.さらに, 各医薬品のインタ ビューフォームにはカプセル内の液体容量の記載がない ため注射器を用いて目的とする投与量を服用することは 不可能である。つまり, 本実験より注射器を用いたカプ セル内の液体を採取する行為は採取者自身が危険を感 じ，さらに採取量にもばらつきを生じ，正確な投与量を 服用することは困難であり推奨できる方法ではないこと が明らかとなった。

次に注射器を用いた液体内容物吸引試験において採取 が困難であったラステット ${ }^{\circledR} \mathrm{S} 25 を$ 用いて簡便にさらに 一定した投与量を服用させる方法について検討した。こ れまでに，倉田ら ${ }^{6)}$ や松ら゙はカプセル剤をそのまま 温湯に入れ, カプセルを崩壊懸濁させてその全量を経管 投与する簡易懸濁法を報告している，その報告ではラス テット ${ }^{\circledR} \mathrm{S} 25$ は簡易懸濁法により投与できるとされてい る。この報告を参考にカプセルを水中で溶解することに より服用する方法を実験的に作成し，1日1カプセル 朝・夕食後服用 $(1$ 回0.5カプセル服用)を想定して実験 を行った. 日本薬局方ではカプセルは $37 \pm 2{ }^{\circ} \mathrm{C}$ の水 $50 \mathrm{~mL}$ でしばしば振り動かすときに10分以内で溶けると規定さ れている，つまり，本実験結果が示すように通常の水道 水の温度ではカプセル溶解には不向きであり, $55^{\circ} \mathrm{C}$ 前後 の温湯でカプセルを溶解しておく必要がある。また，工 トポシドは $65^{\circ} \mathrm{C}, 60$ 日間の保存においても安定であるこ とより $55^{\circ} \mathrm{C}$ の温湯で分解しないと考えられ ${ }^{9)}$, 実測值に おいても $25.11 \mathrm{mg}$ (攪拌群) と $24.69 \mathrm{mg}$ (放置群)とその低 下はみられなかった。ささらに，服用前に溶液を十分攪拌 することで安定した量のエトポシドを服用することが可 能であることが明らかとなった。本実験ではカプセルの 
崩壊はカプセルの形状変化ならびに攪汼の影響を検討す るためにビーカーを用いて行った．倉田ら ${ }^{5,6)}$ の簡易懸 濁法は経管栄養チューブへの注入器具である ExactaMedオーラルディスペンサー $(20 \mathrm{~mL})$ を使用している。 これは懸濁後に懸濁液を全量投与することを前提として いるため，半量ずつの投与を含めて投与量の調節につい

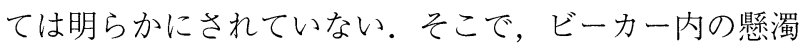
液を注射器もしくはスポイドで採取しエトポイド含量を 測定した。その結果，半量を採取する器具としては注射 器のような先端に残量が生じる器具では含量低下が認め られるため，スポイドのような残量を残さない簡単な構 造の器具が適していることが明らかとなった。また，本 実験は患者への服薬指導の中で注射器ではカプセル剤の 内容液体を吸引採取できなかったという訴えのあったラ ステット ${ }^{\circledR} \mathrm{S} 25 を$ 例にあげ検討を行ったものである。ラ ステット ${ }^{\circledR} \mathrm{S} 25$ は抗癌剤でありその取り扱いには十分注 意する必要がある。そこで，半量を採取する行為につい ての安全性についてアンケート調査を行った結果，7名 中の 5 名は「安全」と回答した。残りの 2 名はラステッ ト ${ }^{\circledR} 25$ は抗癌剤なので「注意を必要」と回答した。さ らに，直接ラステット ${ }^{\circledR} \mathrm{S} 25$ から注射器を用いて内容液 体を採取する方法との比較では全員が「安全」と回答し た。このことより本方法は調製者の感想として安全性の 高いものであると考えられる。その調製者としては患児 やその保護者または薬剤師が考えられるが，安全キャビ ネット外での調製による調製者への抗癌剂の被爆や副作 用の発現に関しての詳細な調査は今後の課題である.

本実験では，内容物が液体であるカプセル剂の液体内 容物の採取方法ならびに投与量調節法について直接注射 器で採取する方法および温湯でカプセルを溶解して採取 する方法で検討を行った，その結果，温湯でカプセルを 溶解して採取する方法はその懸濁液の服用する量を調節 することにより投与量を調節できる可能性について明ら かにした。さらに，本法は小児科領域において低用量の 服用に有効であることのみならず，成人における唖下困 難な患者や肝臓・腎臓機能の低下患者の投与量調節にも
有効である可能性が示唆された。しかしながら，今回は ラステット ${ }^{\circledR} \mathrm{S} 25$ みを用いた検討であるため他の医薬 品での採取方法については今後の検証が必要と考えられ る.

\section{引用文 献}

1) 塩尻容子, 黒㟝勇二, 川㟝博己, 柳沢一恵, 荒木博 陽, 五味田裕, 小田慈, 竹田芳弘, 平木祥夫, QOL 向上への服薬指導: ビタミン $\mathrm{C}$ 含有清涼飲料水に よる内服用ルゴール液服用法の改善, 病院薬学, 24, 677-682 (1998).

2) 北村佳久, 小林有里, 小金一恵, 平松洋子, 荒木博 陽，五味田裕，造血幹細胞移植時に用いる感染予防 薬配合变化の検討一塩酸バンコマイシン散とアムホ テリシン B (ファンギゾンTM シロップ)の混合時の問 題点一, 日本病院薬剤師会雑誌, 37, 1453-1455 (2001).

3）横山紀子, 北村佳久, 二神幸次郎, 荒木博陽, 柴田 和彦，五味田裕，小児の服薬コンプライアンス向上 に向けての医師に対する薬剤師の取り組み, 日本病 院薬剤師会雑誌，39, 977-980 (2003).

4) 末丸克矢, 川上賢哉, 市川裕規, 荒木博陽, 柴田和 彦，二神幸次郎，五味田裕，小児用経鼻チューブの 薬剂透過性, 医療薬学, 29, 337-340 (2003).

5) 倉田なおみ, “内服薬 経管投与ハンドブック一投与 可能薬品一覧表一”, 藤島一郎監修, じほう, 東京, 2001, pp.64-343.

6) 倉田なおみ, 小松千絵, 平藤彰, 森義明, 経管投与 可能な固形製剂の検討と一覧表の作成, 医療薬学, 27, 461-472 (2001).

7) 小松千絵, 荒井千恵, 倉田なお 剤・カプセル剤の粉砕をしない経管投薬法, 月刊薬 事, 46, 689-696 (2004).

8) F.H. Shirazi, G. Bahrami, D.J. Stewart, E. Tomiak, F. Delorme, D. Novel, R. Goel, A rapid reversed phase high performance liquid chromatographic method for determination of etoposide (VP-16) in human plasma, J. Pharm. Biomed. Anal., 25, 353-356 (2001).

9) ラステット ${ }^{\circledR} \mathrm{S} 25$ 医薬品インタビューフォーム, 日本化薬株式会社 (1994). 